\title{
Sustainable Markets: Case Study Of Heinz
}

Dean R. Manna, Robert Morris University, USA

Gayle Marco, Robert Morris University, USA

Brittany Lynn Khalil, Robert Morris University, USA

Cara Esola, Robert Morris University, USA

\begin{abstract}
"The traditional definition of sustainability calls for policies and strategies that meet society's present needs without compromising the ability of future generations to meet their own needs." Sustainability is a concern in private and public sectors all over the world; it is an issue that resonates with people in all age ranges, income levels, and geographic locations. The main idea of sustainability is "reduce, reuse, and recycle." People and organizations alike must consider every possible effect from the decisions they make in regards to the environment.

Sustainability is a challenge in each and every industry, but with the consistent consumption of numerous resources, it is also a necessity. The food industry, like many others, has begun a transformation of its production processes. Drastic changes are being made in the areas of energy consumption, packaging, emissions, and waste. In the United States, between the years 2005 and 2010, "more than 1.5 billion pounds of packaging was diverted from landfills." The goal is increase that number by another 2.5 billion pounds in the next ten years. As of now, the food and beverage industry "is on track to reduce packaging weight by 19 percent, or 2.5 billion pounds, by 2020. That's the energy-saving equivalent of removing 363,000 homes or 815,000 gas-guzzlers. "2 (Cacciola, 2011)
\end{abstract}

As to be expected, Heinz is at the front of the line when it comes to sustainability and originality. The company's sustainable goals are right in line with the industry and the U.S. Government. Three of the sustainable goals Heinz lists are: (1) reducing GHG emissions by twenty percent of the next ten years, (2) reduce energy consumption by $20 \%$, and (3) reduce packaging by $15 \%{ }^{3}$ (The Seed of Heinz's Success, 2011)

Keywords: Sustainability; Food Products; Food Manufacturers

\section{INTRODUCTION: HISTORY OF HEINZ}

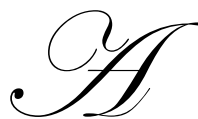

lthough Heinz is most famous for their ketchup, the company actually manufactures thousands of food products that are served in more than 200 countries. Three of their products have dominated their market in share percentage: Ketchup, StarKist brand tuna and Ore-Ida frozen-potatoes. Overall, the company claims to have 150 number one or number two brands worldwide. Geographically, about 55 percent of revenues are generated in North America, 26 percent in Europe, 11 percent in the Asia-Pacific region, and eight percent in other regions.

The company went public by 1900, and became a major name in American business. At that time, Heinz was the number one producer of ketchup, pickles, mustard and vinegar. By this time, their 57 varieties had expanded to over 200 products. Henry Heinz wanted to keep their original slogan of "57" and had a major sign constructed for their factory in New York City. The number 57 was illuminated on a 40 foot long pickle.

Heinz's clever merchandising won him a reputation as an advertising genius, but he did not sway from his religious morals. Throughout his entire lifetime, he never ran his advertisements on a Sunday. Heinz and its companies were the industry's most impressive, both in their facilities and the way their workers were treated. In 1905, just 19 years later, they opened their first factory in England. 
Henry Heinz died in 1919 at the age of 75. At that time, the company had a workforce of 6,500 employees and 25 branch factories. Henry's son Howard became president of the company after his father's death.

By the time Howard's son H.J. Heinz II (known as Jack) became president of the company at his father's death, he had worked in all the company's divisions, from the canning factories to the administrative offices. Jack Heinz was sent by his father to establish a plant in Australia. Heinz-Australia later became that country's biggest food processing plant.

From 1941, when Jack took over, to 1946, H.J. Heinz's sales nearly doubled. That year, Heinz made its first public stock offering and revealed that its net profit was more than $\$ 4$ million. During World War II, Jack Heinz was active in food relief and personally made four wartime trips to England to examine food problems there. Jack Heinz's tenure was distinguished by expansion of the company, both internationally and at home. Subsidiaries were launched in the Netherlands, Venezuela, Japan, Italy, and Portugal. In 1960 and 1961, the H.J. Heinz Company acquired the assets of Reymer \& Bros., Inc. and Hachmeister, Inc. StarKist Foods was acquired in 1963 and Ore-Ida Foods, Inc. in 1965.

During the 25 years that H.J. Heinz II was chief executive, the food industry changed greatly. The era was marked by the rise of supermarket chains and the development of new distribution and marketing systems. In 1969, Anthony (Tony) J.F. O'Reilly became president of the company's profitable British subsidiary. O'Reilly was named president of the parent company, and in 1979 he became CEO. O'Reilly stressed the importance of strong financial results. Overall, O'Reilly's achievements were impressive. The timely acquisition of Hubinger Company in 1975 put Heinz in a position to cash in on the demand for high-fructose corn syrup when the price of sugar soared. In 1978, O'Reilly acquired Weight Watchers International, just ahead of the fitness craze that swept the nation.

By 1980, Heinz had increased volume, while cutting its number of plants from 14 to seven and reducing employment by 18 percent. O'Reilly also gave up the battle with Campbell Soup Company for the retail soup market. When generic products hit the supermarket shelves, Heinz countered not by producing for the generics industry but by "nickel and diming it," as he said. For example, Heinz switched to thinner glass bottles that cut the cost not only of packaging but also of transportation. When imports began to undersell StarKist tuna, StarKist decreased the size of the tuna can, just as Hershey had downsized its chocolate bar when cocoa prices soared. This ploy netted StarKist $\$ 7$ million in savings. Other nickel-and-dime cost savings came from eliminating back labels from bottles, reclaiming heat, and reusing water.

O'Reilly's strategy in the 1980s was to pare costs to the bone and to use the savings to beef up marketing, primarily advertising, in an effort to increase market share. O'Reilly's hard-nosed, bottom-line strategies won Heinz recognition as one of the country's five best-managed companies in 1986. In overseas markets, Heinz began to expand into the Third World. It became the first foreign investor in Zimbabwe when it acquired a controlling interest in Olivine Industries, Inc. in 1982. Heinz also formed joint ventures in Korea and China, and in 1987 the company bought a controlling interest in Win-Chance Foods of Thailand. Win-Chance produced baby food and milk products, and, of course, Heinz planned to add ketchup to the line.

O'Reilly's strategies succeeded in the 1980s. Heinz's sales doubled from $\$ 2.9$ billion in 1980 to $\$ 6.1$ billion in 1990 , and net profits quadrupled to $\$ 504$ million during the period.

But domestic operations were little more than half of Heinz's operations in the 1990s. O'Reilly pinned his expectations for future growth on overseas markets, targeting baby food, in particular, for expansion. Heinz controlled 29 percent of the global infant food market in 1994 and completed the acquisition of Farley's baby food of Great Britain (from the Boots Company PLC) and Glaxo Holdings plc's baby food interests in India that year. Previously unchallenged in international baby food sales, Heinz also buttressed its interests in the Asia/Pacific region with the 1992 purchase of New Zealand's Wattie's The next two years seemed to indicate that O'Reilly's restructuring efforts were paying off for the company. Sales surged ahead by more than $\$ 1$ billion in each of those years, culminating in 1996 revenues of $\$ 9.11$ billion. 
Further acquisitions played a role as well. In December 1994 Heinz paid \$200 million to Kraft General Foods, Inc. for the All American Gourmet Company, maker of the Budget Gourmet line of frozen meals. Heinz nearly doubled the size of its pet food operation through the March 1995 purchase of the North American pet food businesses of the Quaker Oats Company for $\$ 725$ million. They added to the company's existing brands, which included 9-Lives and Amore, were Kibbles'n Bits, Cycle, Gravy Train, and Ken-L Ration, among others. In March 1996 Heinz acquired Boulder, Colorado-based Earth's Best, Inc., a maker of organic baby food.

In March 1997 Heinz launched a major restructuring that involved the closure or sale of 25 plants and a workforce reduction of 2,500, as well as a plan to divest the foodservice operations of the Ore-Ida unit. Heinz also continued to make selective acquisitions, with one of the more important ones being the June 1997 purchase of John West Foods Limited from Unilever. John West was the leading brand of canned tuna and fish in the firm's home country, the United Kingdom. In May 1998 Johnson was named president and CEO of Heinz, with O'Reilly becoming nonexecutive chairman.

Restructuring efforts continued into the early 21st century. In late 1998 the company took a $\$ 150$ million charge to combine the operations of its Ore-Ida Foods and Weight Watchers Gourmet Foods units into a new unit called Heinz Frozen Food Company. Early the following year, Heinz announced its largest restructuring yet. A key component of the program was the realigning of the company along global category lines, a major shift from the previous geographic arrangement. The six main categories, generating 80 percent of global revenues, were ketchup, tuna, frozen foods, infant foods, pet foods, and convenience meals. Heinz also planned to concentrate on the six countries that generated 80 percent of the company's revenues: the United States, the United Kingdom, Italy, Canada, Australia, and New Zealand.

In late 1999 Heinz completed the sale of the Weight Watchers diet class unit to Artal Luxembourg, S.A., a European venture capital firm. The company gained a foothold in the fast-growing natural and organic foods sector through the purchase of a 19.5 percent stake in Hain Food Group Inc. for $\$ 100$ million. The Hain product line included Health Valley cereal and other products, Terra Chip snacks, and Westsoy soy beverages. Through the alliance with Heinz, Hain also acquired the Earth's Best line of organic baby foods. In May 2000 Hain acquired Celestial Seasonings, best known for its herbal teas.

\section{HEINZ'S MISSION RELATED TO SUSTAINABILITY}

Heinz mission statement is "As a trusted leader in nutrition and wellness, Heinz-the original Pure Food Company-dedicated to the sustainable health of people, the plant and our company." With this mission statement it is clear to see how important sustainability it to the company. Heinz also has five main values that they follow within their company.

1. Team building and collaboration.

This is the value in which they chose to embrace great ideas from everywhere and everyone and respect all individuals.

2. Innovation

This is where they believe in spotting consumer and customer needs and meeting them with simply, creative solutions.

3. Vision

This is where they define a compelling, sustainable future and create a path to achieve it.

4. $\quad$ Strives for is results

This is where they deliver on commitments, take accountability and balance the short and long term.

5. Company integrity

This is where they always tell the truth, act with the highest ethical standards and ensure that their products are of the highest quality. 


\section{HEINZ'S ORGANIZATIONAL STRUCTURE}

Organizational structure differs from company to company based on their objectives and environment. At Heinz, their main focus is sustaining a strong system of corporate governance. Heinz believes that by operating in this manner, they are able to operate in both an ethically and social manner, all the while, making sure both the shareholders and the community are accounted for in the company.

The center of Heinz is run by 12 members of the Board of Directors. Heinz directors are all elected by its shareholders, which includes 11 independent directors. Independent board members are those that do not take part in the company other than their affiliation with the board. The Board of Directors is led by the Heinz Chairman, President, and CEO. The Board of Directors is responsible for many things, with their main goal to improve longterm strategy and increase their shareholders value. Also, the Board of Directors has adopted its principles that specify how the company should be run, including their role, composition, functions, and structures. To add diversity to their Board of directors, Heinz ended its fiscal year of 2008 with two female and two minority directors.

Heinz has a set way in which they operate their company. They website stated the following on how they structure Heinz:

"The Board of Directors believes that good corporate governance principles and practices provide a sound framework to assist the Board in fulfilling its responsibilities to shareholders. The Board recognizes the interests of the Company's shareholders, employees, customers, supplies, consumers, creditors and the communities in which the company operates, who are all essential to the Company's success. Accordingly, the Board has adopted these principles relating to its role, composition, structure and functions. The Board periodically reviews these principles and other aspects of its corporate governance framework, including Board committee charters."

This quote, in a nutshell, describes how Heinz runs its company.

\section{HEINZ'S PRODUCT LINE}

Heinz has a phrase that describes their product line, "Heinz is proud to introduce you to our entire family of products around the globe." This statement holds true about Heinz, manufacturer of thousands of food products in over 20 countries across the world. They sell products in the category of ketchup and sauces, meals and snacks, and infant/ nutrition, just to name a few. Within these categories, are brand names such as Classico, Lea \& Perrins, Bagel Bites, Boston Market, Ore-Ida, and Nurture, which have made Heinz the successful company that it is today. Heinz ranked first with its ketchup line in the United States holding over 50 percent of the market share. Another brand that was a huge success in the United States was Ore-Ida, also holding more than 50 percent of the frozen-potato sector. In total, Heinz claims to have approximately150 brands in either first or second place in market share worldwide. The condiment line is one of Heinz major product lines accounting for nearly 24 percent of their overall sales, with frozen food coming in at 15 percent, followed then by pastas, soups, etc at 14 percent. All the other product categories fall behind these percentages. Geographically, Heinz is famous worldwide but most of its revenues seem to be generated in North America, holding about 55 percent of the revenue. Following after North America, is Europe then Asia-Pacific concluding with the other percents of revenue scattered elsewhere.

As stated before, although Heinz is most known for its Ketchup and condiment lines of products, they are more famously known for 15 key brands globally. These brands include ABC, Bagel Bites, Boston Market, Chef Francisco, Classico, Delimex, Heinz, Honig, Ore-Ida, Plasmon, Pudliszki, Smart Ones, TGI Fridays, Wattie's, and Weight Watchers. Heinz has diverse product lines in different categories of food, going from its most famous here in Pittsburgh, condiments, to frozen foods. The wide variety that Heinz has been able to offer over the years worldwide proves the strength in their diversity of product lines, aiming to please customers in all different spectrums of the food categories. They have successfully accomplished pleasing customers in many categories of their products.

\section{HEINZ'S GOALS ON SUSTAINABLE ISSUES RELATED TO THEIR OPERATION}

As previously mentioned, Heinz has set forth a number of goals that they hope to reach in sustainability within their company. Through the recognition they have received, it is clear to see they are working hard to reach 
the goals set forth by their company. A list of Heinz key sustainability goals are as follows:

- $\quad$ Reduce GHG emissions by $20 \%$ over 10 years

- $\quad$ Energy consumption $-20 \%$ reduction through improved operational efficiency

- Packaging - 15\% reduction by the introduction of alternative packaging materials and reduction of existing packaging use

- $\quad$ Transportation - $10 \%$ reduction through improved efficiency of distribution network

- $\quad$ Solid Waste $-20 \%$ reduction through increased recycling and reuse of waste

- $\quad$ Renewable energy $-15 \%$ to come from renewable sources, including solar, biomass and bio-gas

- $\quad$ Agriculture $-15 \%$ reduction of carbon footprint, $15 \%$ reduction of water usage, improvement of yields by $5 \%$ through use of hybrid tomato seeds that require less water, fertilizer, pesticides and fuel to harvest

- Water $-20 \%$ reduction through reuse and improved sanitation techniques

- $\quad$ Employees - Increase employee engagement through a voluntary personal sustainability campaign

\section{CHANGES MADE AS A RESULT OF THE SUSTAINABLE GOALS}

In striving for the above goals, Heinz had made major changes at many of its worldwide locations, from Ireland to Poland to Indonesia.

- $\quad$ At the Dundalk facility in Ireland they recycle 99\% of the cardboard, wood, and steel they use, and 95\% of the plastic. The recently installed a new condenser at this location as well which is expected to reduce annual electricity consumption by $566,000 \mathrm{kWh}$ and reduce carbon dioxide emissions by $366,400 \mathrm{~kg}$.

- $\quad$ At the Heinz Seesen facility in Germany, they installed and reengineered cooling water pumps reducing annual electricity by $297,000 \mathrm{kWh}$. Also, they lowered gas consumption by $67,875 \mathrm{~m}^{3}$ by reducing steam pressure.

- $\quad$ Kitt Green, Heinz's largest food processing facility in Europe, modified their cookers, sterilizers, and coolers therefore reducing direct carbon dioxide emissions by 5\%. Also, Kitt Green reduced landfill waste and implemented a program encouraging employees to bicycle to work because it would be better for the environment.

- In Indonesia, Heinz switched to thinner packaging and has reduced the weight of its glass soy sauce bottles which in turn reduced tinplate consumption by $10 \%$.

- Heinz Poland also converted to thinner packaging which reduced its consumption of shrink-wrap foil by $40 \%$.

- $\quad$ The Heinz's facility in Leamington, Canada, implemented a bean soak system to reduce water usage and organic load, which further enhanced the quality of Heinz beans for processing. Steam trap upgrades also helped the plant increase condensate capture for reuse in boilers, reducing water and chemical waste.

- Other locations in which changes have been made to ensure the most sustainable company include India, New Zealand, Venezuela, Costa Rica, and Mexico.

- $\quad$ The location in which we see the greatest strides towards sustainability is here in the United States. Many of the Heinz locations across the United States have made changes to better the company socially, environmentally and economically.

- Heinz's Fremont, Ohio, facility reduced solid landfill waste by recycling 350,000 lbs. of plastic materials and 51,860 lbs. of metal materials.

- The Heinz in Mason, Ohio eliminated 625,000 lbs. of metal waste through program improvements, preventative maintenance schedules and various controls.

- $\quad$ The Chatsworth, California, facility launched a program to recapture steam condensate, resulting in conserving more than 3.1 million gallons of water and using less gas. The facility also installed energyefficient lighting to save $828,522 \mathrm{kWh}$ annually.

- $\quad$ The Portion Pac facility in Dallas recycled almost 1.2 million lbs. of material.

- In Atlanta, the Heinz Portion Pac facility initiated a plastic recycling program in 2006 that cut landfill waste by $7,280 \mathrm{lbs}$. 
- $\quad$ The Cedar Rapids, Iowa, facility implemented refrigeration utility monitoring to reduce electricity consumption by 2.77 million $\mathrm{kWh}$. It also replaced lighting to achieve an additional reduction of 590,712 $\mathrm{kWh}$.

- $\quad$ The Escalon, California, facility reduced natural gas usage by 100,000 thm per year and wastewater by 100,000 gallons a day.

- $\quad$ The Jacksonville, Florida, facility recycled plastic drums, fiber drums, metal barrels and plastic pails to reduce landfill waste by a total of more than 148,000 lbs. in a six-month period through April 2007. It also cut electricity consumption by $607,458 \mathrm{kWh}$.

\section{HEINZ'S SOCIAL AND ECONOMIC SUSTAINABLE INITIATIVES}

Aside from their environmental sustainability, they also excel at social and economic sustainability.

Heinz has extremely strong fiscal results because of their investments in marketing, innovation, and research and development. Heinz has a legacy of providing fair treatment, competitive wages, equal opportunity, and safe and humane working conditions for all employees worldwide. Heinz employees approximately 32,500 people worldwide. They pay their employees competitive wages that company with local laws and in many cases typically exceed the minimum wage standards. Furthermore, nearly all of Heinz employees are members of surrounding communities; therefore they are supporting the local communities.

Aside from the competitive wages that Heinz provides for its employees, they also make a positive impact by funding retirement benefit plans, as well as pension plans. Another positive impact created by Heinz is that they enhance the tax revenue of the communities and even the nations where they do business. One example of how Heinz has stepped up to help employees is how they enhanced their maternity/paternity benefits for U.S. salaried employees beyond the federal Family Medical Leave Act, which offers 12 weeks unpaid leave for employees. New mothers who are Heinz employees now receive up to six weeks of paid leave while fathers receive one week.

\section{HEINZ'S CHARITABLE INITIATIVES}

Heinz is well known for the charitable contribution that they have made which have had a powerful impact on the communities where people live and work. With these charitable contributions, Heinz emphasizes on promoting health, nutrition, and the well-being of children and families. Heinz participates in seven popular charitable activities, which are each listed with a description below, which can be found on the Heinz website:

\section{- $\quad$ Tomatosphere}

Tomatosphere is a project that uses the excitement of space exploration as a medium for teaching students about science, space and agriculture. Both Canadian and U.S. classrooms in grades 2-10 conduct experiments to investigate the effects of the space environment on the growth of food (specifically, Heinz tomato seed). These results may be used to support a long-term human mission. In 2009, 10,500 Canadian and U.S. classrooms were enrolled in the program. A recent teacher evaluation revealed $98 \%$ of educators believed the project increased student interest in science and 92\% indicated that the project met their classroom needs.

\section{- Operation Warm}

Operation Warm is a national non-profit organization that provides new winter coats to children in need. In Pittsburgh, Pennsylvania, Operation Warm provided more than 6,500 children with new winter coats in 2008. Funding from the H.J. Heinz Company Foundation enabled Operation Warm to provide new winter coats to children served by the Extra Mile Education Foundation.

- $\quad$ Pittsburgh Public Theater

Pittsburgh Public Theater is nationally renowned for the quality of its stage productions and the tremendous range and diversity of its programming. Each season, the Theater welcomes approximately 100,000 adults and young people. With the help of the H.J. Heinz Company Foundation and other community partners, Pittsburgh Public Theater ended its last five seasons on budget. 
- $\quad$ Sandusky County Food Pantry, Ohio

The Sandusky County Food Pantry works in cooperation with area churches and public agencies to provide emergency food supplies to needy families in the area. The food pantry has helped families in need each month with the funding from Heinz.

- $\quad$ Stockton Homeless Shelter, California

A Heinz grant to the Stockton Homeless Shelter provided additional sleeping areas for families and women who could not be accommodated in the family shelter.

- $\quad$ Muscatine Charities, Iowa

Muscatine Charities, working with the Muscatine Community School District, established an after-school program that targeted children who had difficulty completing their homework and were falling behind in class. With Heinz's support, 502 participants showed marked improvements in attendance rates and their pass rates were consistently at $95-98 \%$.

- $\quad$ Ronald McDonald House of Jacksonville, Florida

The Community Grants Program was able to assist the Ronald McDonald House of Jacksonville with the Direct Family Care Project. The program provides reliable van transportation to and from the hospital for the families utilizing the Ronald McDonald House.

\section{CONCLUSION}

Through my research, it became very clear that Heinz strives to be as sustainable as possible, even stating that they are dedicated to sustainability in their company's mission statement. They were very successful in their sustainability goals in the past couple of years and were recognized for several awards. Heinz was rated as a sustainability leader in North America in 2008 and 2009 by the Dow Jones Sustainability Indexes (DJSI). The DJSI was first launched in 1999 to create global indexes tracking the financial performances of the leading sustainable companies in North America. Also, in 2008 Heinz was recognized by the Carbon Disclosure Project, ranking third among leading companies for it approach to climate change disclosure in the retail and consumer segment, and ranked first among food manufacturers. Heinz ranked among the 50 most environmentally and socially responsible companies in 2007 in the Lifestyles of Health and Sustainability Index. Also in 2007, Heinz was listed among the 100 Best Corporate Citizens in the Corporate Responsibility Officer Magazine. The CEO of Heinz was even selected for an award due to his efforts towards sustainability and was selected as the CEO Pioneer for Corporate Social Responsibility by $P R$ News. All of these awards are very prestigious and show the effort that Heinz has put into its company to maintain and build its sustainability.

\section{AUTHOR INFORMATION}

Dean R. Manna, Ph.D. has consulted for private industry, government, and the public sector for thirty years in the areas of sales, management, customer relations, and marketing. He has published a complete instructional manual on Client Centered Selling for use in the classroom and corporate training. His teaching specialty is in the area of Professional Selling both at the undergraduate and graduate level. Dr. Manna's primary research interest is on Emotional Intelligence and its effects on productivity and morale in the public and private sector.

Dr. Manna was a past president of the Pittsburgh Chapter of the American Marketing Association. He holds his undergraduate degree in Business from Gannon University, an MBA from the University of Cincinnati, and his $\mathrm{Ph} . \mathrm{D}$. from the University of Pittsburgh. He is a University Professor of Marketing and Department Head of the Marketing Department in the School of Business at Robert Morris University. E-mail: Manna@rmu.edu

Gayle Marco, Ph.D. received her Ph.D. degree from the University of Pittsburgh. (Major: Marketing Education and Vocational Education) Her research interests include various areas of consumer decision making, buyer behavior and the various areas of sustainability. She has consulted for numerous companies in the Pittsburgh area. The consulting areas include product repositioning, market development for new products, needs assessments, and market plan development. Professor Marco integrates "real" marketing projects for area businesses in her teaching at the undergraduate and graduate level. She has published in the Journal of Global Business, The Journal of American Academy of Business, American Journal of Business Education, and Journal of Business Case Studies as well as numerous conference proceedings. E-mail: marco@rmu.edu 
Brittany Khalil, I am an integrated student at Robert Morris University pursuing a Bachelor Degree in Marketing and a Master Degree in Competitive Intelligence. During my time at Robert Morris University (RMU), I have been a member of the RMU chapter of the American Marketing Association and served as an officer for one year. I created an outline for a sustainable committee for RMU, which was presented at the sustainable conference on campus. I have also made the Dean's List the past two years.

Cara Esola graduated from Robert Morris University in May 2010 with a concentration in Marketing.

\section{REFERENCES}

1. Agency, U.E. (2010, November 17). Sustainability: Basic Information. Retrieved December 21, 2010, from EPA: http://www.epa.gov/sustainability/basicinfo.htm\#sustainability

2. Cacciola, J. (2011, March 24). U.S. Food Industry To Trim Packaging Waste by 4 Billion Pounds. Retrieved April 12, 2011, from SlashFood: http://www.slashfood.com/2011/03/24u-s-food-industry-totrim-packaging-waste-by-4-billion-pounds/

3. The Seed of Heinz's Success. (2011). Retrieved April 12, 2011, from Heinz: http://www.heinz.com/ sustainability.aspx

4. $\quad$ http://www.heinz.com/sustainability.aspx 